\title{
Risk of hypertension with bevacizumab, an antibody against vascular endothelial growth factor $A$ : a systematic review and meta-analysis
}

\author{
Mandar K. Shah ${ }^{1}$, Mihika A. Shah ${ }^{1}$, Sharan D. Shah ${ }^{2}$
}

${ }^{1}$ NHL Medical College, Ahmedabad, Gujarat, India

${ }^{2}$ AMC Dental College,

Ahmedabad, Gujarat, India

Received: 05 September 2019

Revised: 21 September 2019

Accepted: 23 September 2019

\section{*Correspondence to: \\ Mandar K. Shah, \\ Email: shahmandar20@ \\ gmail.com}

Copyright: (C) the author(s), publisher and licensee Medip Academy. This is an openaccess article distributed under the terms of the Creative Commons Attribution NonCommercial License, which permits unrestricted noncommercial use, distribution, and reproduction in any medium, provided the original work is properly cited.

\begin{abstract}
Bevacizumab, a humanized antibody against VEGF, is effective in the treatment of patients with many cancers. However, as with many therapeutic agents, significant side effects are associated with bevacizumab, Hypertension is one of the predominant toxicity. We performed a systematic review and meta-analysis of published clinical trials of bevacizumab to quantify the risk of hypertension. 15 studies following PRISMA guidelines and matching inclusion and exclusion criteria were collected in which a group of patients were either treated with Bevacizumab and a concurrent chemotherapy and another group treated with Placebo and the same chemotherapy. Relative risk (RR) was calculated. $\mathrm{P}<0.05$ was considered statistically significant. RevMan 5.3 software was used for the analysis. A total of 13,070 patients were included. Bevacizumab was associated with a significant increased risk of overall hypertension $(\mathrm{RR}=3.509 ; 95 \%$ C.I:2.451 to 5.023). 11 trials are included for determining the risk of Grade 3 hypertension including 8799 patients with a significant increased risk $(\mathrm{RR}=3.909 ; 95 \%$ C.I:1.983 to 7.707). 7 trials are included for determining the risk of hypertension at low dose $(2.5 \mathrm{mg} / \mathrm{kg} / \mathrm{cycle})$ including 3691 patients associated with a significant increased ( $R R=2.640$; 95\%C.I: 1.408 to 4.950$) .10$ trials are included for determining the risk of hypertension at high dose (5 $\mathrm{mg} / \mathrm{kg} /$ cycle) including 9379 patients associated with a significant $(\mathrm{RR}=4.036$; 95\% C.I: 2.948 to 5.525 ). Our meta-analysis has demonstrated that bevacizumab may be associated with a significantly increased risk of hypertension in patient with a variety of metastatic solid tumors irrespective of dosing.
\end{abstract}

Keywords: Bevacizumab, Anti-cancer, Placebo, Hypertension

\section{INTRODUCTION}

Tumor angiogenesis is critical for tumor progression. The vascular endothelial growth factor (VEGF) promotes angiogenesis and over expression of the VEGF has been correlated with poor prognosis in various malignancies. ${ }^{1,2}$ There are 2 main targets in the VEGF signaling pathway: VEGF ligands and VEGF receptors (VEGFRs). Bevacizumab, a humanized antibody against VEGF, is effective in the treatment of patients with many cancers, such as metastatic colorectal cancer, non-small-cell lung cancer, and breast cancer, shown by several phase III studies. ${ }^{1-4}$ There also are promising phase II clinical trials in patients with pancreatic cancer, renal cell cancer, and prostate cancer. However, as with many therapeutic agents, significant side effects are associated with bevacizumab, including thrombosis, wound-healing complications, bleeding, gastrointestinal perforation, and renal toxicity. Hypertension is the predominant toxicity. ${ }^{3}$ Severe hypertension including hypertensive crisis may cause significant cardiovascular damage with a possible life-threatening consequence, and limit the use of bevacizumab. The incidences of high-grade (grade 3-4) hypertension in patients receiving bevacizumab varied 
substantially among clinical trials. ${ }^{4}$ The overall risk hypertension in patients with cancer on bevacizumab therapy is unclear. We performed a systematic review and meta-analysis of published clinical trials of bevacizumab to quantify the risk of hypertension. The use of Bevacizumab in cancer has been increasing nowadays in India, due to lack of many systematic reviews determining the risk of this novel anticancer agent we decided to perform a meta-analysis.

\section{METHODS}

\section{Step 1: Identification and literature search}

The search was done based on preferred reporting system for meta-analysis and systemic review (PRISMA) guideline. ${ }^{5}$ All the scientific database like clinical trials.gov, Pub med central, NCBI, NIH, Cochrane Library and Google scholar were used for search cancer, Bevacizumab, side-effects, hypertension. All the trials published after January 2004 to till date were included in search.

\section{Step 2: Criteria for selection of studies}

All study related randomised controlled trials (RCTs) using either:

- An adequate method of allocation concealment (e.g. sealed opaque envelopes),

- Studies that were double-blind, single-blind or unblinded,

- Studies that were in Phase 2 or Phase 3 trial were only included.

\section{Step 3: RCT enrolment criteria}

\section{Inclusion criteria}

Inclusion criteria were the study must include the participants greater than or equal to 18 years of age; the studies which included bevacizumab plus a concurrent therapy and placebo with a concurrent therapy were only included; the dose of bevacizumab should be 2.5 $\mathrm{mg} / \mathrm{kg} /$ week or $5 \mathrm{mg} / \mathrm{kg} /$ week.

\section{Exclusion criteria}

Exclusion criteria were studies including patients prior treated with bevacizumab or another drug that targets VEGF-A pathway or other malignancies within 5 years (unless low risk of recurrence); also the studies with history of abdominal fistula, gastrointestinal perforation, intra-abdominal abscess, clinical signs or symptoms of gastrointestinal obstruction, and/or requirement of parenteral nutrition, non-healing wound, ulcer. Bone fracture, bleeding diathesis, coagulopathy, known CNS disease (except for treated brain metastasis), clinically significant cardiovascular disease, a major surgical procedure within 28 days of enrollment or anticipated to occur while participating in study were excluded from the analysis; unpublished research work or trials.
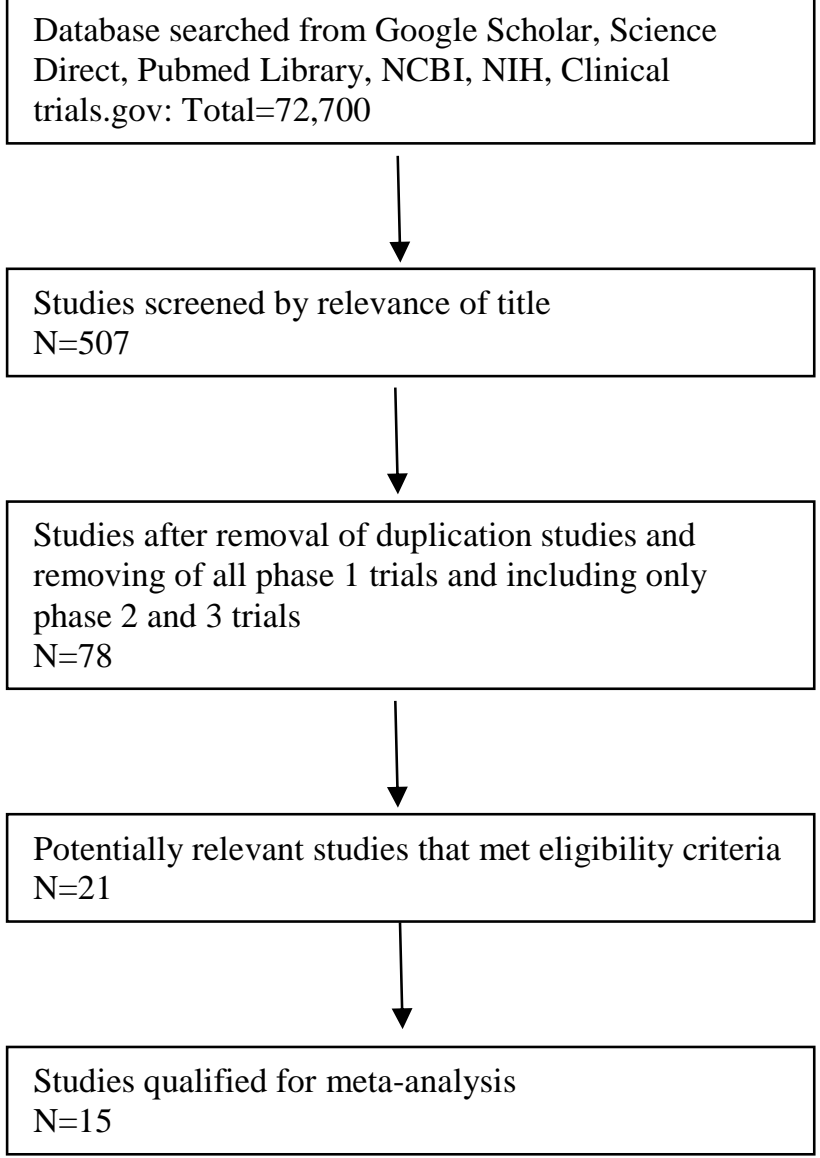

Figure 1: PRISMA flow diagram of included articles.

\section{Step 4: Type of intervention}

Patients treated by bevacizumab with concurrent chemotherapy and placebo with concurrent chemotherapy in clinical trial (phase 2 or 3 ) of cancer.

\section{Step 5: Outcome measure of side effect}

Outcome for measurement of Hypertension and grade was according to National Cancer Institute Common Terminology criteria version 3. Outcome was measured after 6 cycles for 6 studies and till overall survival in 9 .

\section{Step 6: Data extraction}

Data were extracted from studies meeting above criteria. Those studies in which data was unclear asked from respective authors. In some studies, data could not obtain by enquiry were excluded.

\section{Step 7: Nullification of bias}

Authors assured to include studies in which allocation of both the groups were adequately randomized and there was no any conflict of interest as well as match to 
inclusion and exclusion criteria. Also the concurrent treatment was same for the group with bevacizumab therapy and placebo therapy.

\section{Step 8: Measurement of relative risk}

The outcome of the occurrence of hypertension (both any grade and above grade 3 ) was recorded from both the groups (bevacizumab and placebo) and relative risk (RR) was calculated with $95 \%$ confidence interval and funnel as well as forest plot was obtained. RevMan ${ }^{\circ}$ Version 5.38 was used for analysis. $\mathrm{P}$ value less than 0.05 were considered significant.

\section{RESULTS}

Individual searches yield total of studies, from which 15 included all grade hypertension, 11 studies included grade 3 hypertension and above, 7 studies included bevacizumab with dose $2.5 \mathrm{mg} / \mathrm{kg} /$ cycle and 10 studies included bevacizumab with dose $5 \mathrm{mg} / \mathrm{kg} / \mathrm{cycle}$. [The trials of Miles et al, and Reck et al, had both dosing cycles so were included in both low and high dosing regimens. ${ }^{10,18}$

Table 1: Characteristics of randomized controlled clinical trials included in the meta-analysis.

\begin{tabular}{|c|c|c|c|}
\hline Study name & Underlying malignancy & Concurrent treatment & Bevacizumab dose \\
\hline Ohtsu et al $^{6}$ & Advanced gastric cancer & Fluropyrimidine-cisplatin & $2.5 \mathrm{mg} / \mathrm{kg} / \mathrm{every}$ week \\
\hline 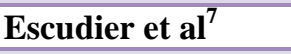 & Metastatic renal cell carcinoma & Interforon alfa & $5 \mathrm{mg} / \mathrm{kg} /$ week \\
\hline Aghajanian et al ${ }^{8}$ & $\begin{array}{l}\text { Recurrent epithelial ovarian, } \\
\text { primary peritoneal, or }\end{array}$ & Gemcitabine plus carboplatin; & $5 \mathrm{mg} / \mathrm{kg}$ every week \\
\hline Zhou et al ${ }^{9}$ & $\begin{array}{l}\text { Recurrent non squamous non small } \\
\text { cell lung cancer }\end{array}$ & Pacitaxel or carboplatin & $5 \mathrm{mg} / \mathrm{kg}$ every week \\
\hline Miles et al ${ }^{10}$ & HER 2- metastatic breast cancer & Docetaxel & $2.5 \mathrm{mg} / \mathrm{kg} /$ week \\
\hline Miles et al $^{10}$ & HER 2- metastatic breast cancer & Docetaxel & $5 \mathrm{mg} / \mathrm{kg} /$ week \\
\hline Cutsem et al ${ }^{11}$ & Metastatic pancreatic cancer & Gemcitabine and erlotinib & $2.5 \mathrm{mg} / \mathrm{kg} /$ week \\
\hline${\text { Kabbinavar et } \text { al }^{12}}^{12}$ & Metastatic colon cancer & Bolus fluorouracil and leucovorin & $2.5 \mathrm{mg} / \mathrm{kg}$ every week \\
\hline Hurwitz et al ${ }^{13}$ & Metastatic colon cancer & $\begin{array}{l}\text { Irinotecan, bolus fluorouracil, and } \\
\text { leucovorin }\end{array}$ & $2.5 \mathrm{mg} / \mathrm{kg}$ every week \\
\hline Hurwitz et al ${ }^{14}$ & Metastatic colorectal cancer & Irinotecan/fluorouracil/leucovorin & $2.5 \mathrm{mg} / \mathrm{kg} /$ week \\
\hline Hurwitz et al ${ }^{15}$ & Metastatic colorectal cancer & Oxaliplatin-based, irinotecan based & $5 \mathrm{mg} / \mathrm{kg} /$ week \\
\hline Kindler et al ${ }^{16}$ & Advanced pancreatic cancer & Gemcitabine & $5 \mathrm{mg} / \mathrm{kg} /$ week \\
\hline Kindler et al $^{17}$ & Malignant mesothelioma & Gemcitabine and cisplatin & $5 \mathrm{mg} / \mathrm{kg}$ every week \\
\hline Reck et al ${ }^{18}$ & $\begin{array}{l}\text { Nonsquamous non-small-cell lung } \\
\text { cancer }\end{array}$ & Cisplatin and gemcitabine & $2.5 \mathrm{mg} / \mathrm{kg}$ every week \\
\hline Reck et al $^{18}$ & $\begin{array}{l}\text { Nonsquamous non-small-cell lung } \\
\text { cancer }\end{array}$ & Cisplatin and gemcitabine & $5 \mathrm{mg} / \mathrm{kg}$ every week \\
\hline Robert et al ${ }^{19}$ & $\begin{array}{l}\text { HER 2- locally recurrent or } \\
\text { metastatic breast cancer }\end{array}$ & Capecitabine, taxane, anthracycline & $5 \mathrm{mg} / \mathrm{kg}$ every week \\
\hline Burger et al $^{20}$ & Ovarian cancer & Carboplatin and Pacitaxel & $5 \mathrm{mg} / \mathrm{kg}$ every week \\
\hline
\end{tabular}

Table 2: Characteristics of randomized controlled clinical trials included in the meta-analysis.

\begin{tabular}{|c|c|c|c|c|c|}
\hline Study name & $\begin{array}{l}\text { Trial } \\
\text { phase }\end{array}$ & $\begin{array}{l}\text { Number for analysis } \\
\text { bevacizumab } \\
\text { group }(\mathbf{N})\end{array}$ & $\begin{array}{l}\text { Number for } \\
\text { analysis placebo } \\
\text { group }(\mathbf{N})\end{array}$ & $\begin{array}{l}\text { Hypertension in } \\
\text { bevacizumab } \\
\text { group }\end{array}$ & $\begin{array}{l}\text { Hypertension } \\
\text { in placebo } \\
\text { group }\end{array}$ \\
\hline Ohtsu et al ${ }^{6}$ & 3 & 386 & 381 & 24 & 2 \\
\hline Escudier et al $^{7}$ & 3 & 337 & 304 & 88 & 28 \\
\hline${\text { Aghajanian et } \text { al }^{8}}$ & 3 & 247 & 233 & 43 & 1 \\
\hline 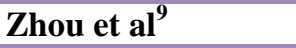 & 3 & 140 & 134 & 7 & 1 \\
\hline Miles et al ${ }^{10}$ & 3 & 252 & 231 & 2 & 3 \\
\hline Miles et al ${ }^{10}$ & 3 & 247 & 231 & 11 & 3 \\
\hline Cutsem et al ${ }^{11}$ & 3 & 296 & 287 & 60 & 26 \\
\hline Kabbinavar et al ${ }^{12}$ & 2 & 100 & 104 & 32 & 5 \\
\hline Hurwitz et al ${ }^{13}$ & 2 & 393 & 397 & 88 & 33 \\
\hline Hurwitz et al ${ }^{14}$ & 3 & 109 & 98 & 37 & 37 \\
\hline Hurwitz et al ${ }^{15}$ & 3 & 1990 & 1773 & 153 & 29 \\
\hline Kindler et al ${ }^{16}$ & 3 & 277 & 263 & 10 & 3 \\
\hline
\end{tabular}

Continued. 


\begin{tabular}{|llllll|} 
Study name & $\begin{array}{l}\text { Trial } \\
\text { phase }\end{array}$ & $\begin{array}{l}\text { Number for analysis } \\
\text { bevacizumab } \\
\text { group (N) }\end{array}$ & $\begin{array}{l}\text { Number for } \\
\text { analysis placebo } \\
\text { group (N) }\end{array}$ & $\begin{array}{l}\text { Hypertension in } \\
\text { bevacizumab } \\
\text { group }\end{array}$ & $\begin{array}{l}\text { Hypertension } \\
\text { in placebo } \\
\text { group }\end{array}$ \\
\hline Kindler et al $^{\mathbf{1 7}}$ & 2 & 53 & 55 & 23 & 9 \\
\hline Reck et al $^{\mathbf{1 8}}$ & 3 & 330 & 327 & 21 & 5 \\
\hline Reck et al $^{\mathbf{1 8}}$ & 3 & 329 & 327 & 28 & 5 \\
\hline Robert et al $^{\mathbf{1 9}}$ & 3 & 817 & 413 & 81 & 4 \\
\hline Burger et al $^{\mathbf{0}}$ & 3 & 608 & 601 & 139 & 43 \\
\hline
\end{tabular}

Table 3: Relative risk of all grade hypertension in bevacizumab versus placebo.

\begin{tabular}{|c|c|c|c|c|c|c|c|c|}
\hline \multirow{2}{*}{ Study } & \multirow{2}{*}{$\begin{array}{l}\text { Bevacizumab } \\
\text { (N) }\end{array}$} & \multirow{2}{*}{$\begin{array}{l}\text { Placebo } \\
(\mathbf{N})\end{array}$} & \multirow{2}{*}{$\begin{array}{l}\text { Relative } \\
\text { risk }\end{array}$} & \multirow{2}{*}{$95 \% \mathrm{CI}$} & \multirow{2}{*}{$\mathbf{z}$} & \multirow{2}{*}{$\begin{array}{l}P \\
\text { value }\end{array}$} & \multicolumn{2}{|c|}{ Weight (\%) } \\
\hline & & & & & & & Fixed & Random \\
\hline Ohtsu et al $^{6}$ & $24 / 386$ & $2 / 381$ & 11.845 & 2.819 to 49.771 & & & 0.94 & 3.74 \\
\hline Escudier et al $^{7}$ & $88 / 337$ & $28 / 304$ & 2.835 & 1.908 to 4.213 & & & 12.34 & 8.37 \\
\hline Aghajanian et al ${ }^{8}$ & $43 / 247$ & $1 / 233$ & 40.563 & 5.631 to 292.193 & & & 0.50 & 2.44 \\
\hline Zhou et al $^{9}$ & $7 / 140$ & $1 / 134$ & 6.700 & 0.835 to 53.732 & & & 0.45 & 2.25 \\
\hline Miles et al ${ }^{10}$ & $2 / 252$ & $3 / 231$ & 0.611 & 0.103 to 3.625 & & & 0.61 & 2.83 \\
\hline Miles et al ${ }^{10}$ & $11 / 247$ & $3 / 231$ & 3.429 & 0.969 to 12.137 & & & 1.21 & 4.32 \\
\hline Cutsem et al ${ }^{11}$ & $60 / 296$ & $26 / 287$ & 2.238 & 1.455 to 3.442 & & & 10.44 & 8.22 \\
\hline Kabbinavar et al ${ }^{12}$ & $32 / 100$ & $5 / 104$ & 6.656 & 2.702 to 16.399 & & & 2.38 & 5.87 \\
\hline Hurwitz et al ${ }^{13}$ & $88 / 393$ & $33 / 397$ & 2.694 & 1.851 to 3.919 & & & 13.76 & 8.46 \\
\hline Hurwitz et al ${ }^{14}$ & $37 / 109$ & $37 / 98$ & 0.899 & 0.624 to 1.295 & & & 14.53 & 8.50 \\
\hline Hurwitz et al $^{15}$ & $153 / 1990$ & $29 / 1773$ & 4.701 & 3.177 to 6.955 & & & 12.61 & 8.39 \\
\hline Kindler et al $^{16}$ & $10 / 277$ & $3 / 263$ & 3.165 & 0.881 to 11.373 & & & 1.18 & 4.26 \\
\hline Kindler et al $^{17}$ & $23 / 53$ & $9 / 55$ & 2.652 & 1.354 to 5.193 & & & 4.29 & 7.02 \\
\hline Reck et $_{\text {al }}{ }^{18}$ & $21 / 330$ & $5 / 327$ & 4.162 & 1.588 to 10.905 & & & 2.09 & 5.57 \\
\hline Reck et al ${ }^{18}$ & $28 / 329$ & $5 / 327$ & 5.566 & 2.176 to 14.237 & & & 2.19 & 5.69 \\
\hline Robert et al ${ }^{19}$ & $81 / 817$ & $4 / 413$ & 10.237 & 3.777 to 27.740 & & & 1.95 & 5.42 \\
\hline Burger et al $^{20}$ & $139 / 608$ & $43 / 601$ & 3.195 & 2.314 to 4.413 & & & 18.56 & 8.66 \\
\hline Total (fixed effects) & $847 / 6911$ & $237 / 6159$ & 3.288 & 2.865 to 3.774 & 16.936 & $<0.001$ & 100.00 & 100.00 \\
\hline $\begin{array}{l}\text { Total (random } \\
\text { effects) }\end{array}$ & $847 / 6911$ & $237 / 6159$ & 3.509 & 2.451 to 5.023 & 6.859 & $<0.001$ & 100.00 & 100.00 \\
\hline
\end{tabular}

Heterogeneity, $\mathrm{Q}=78.7471$, degree of freedom $=16, \mathrm{p}<0.0001, \mathrm{I}^{2}$ (inconsistency) $=79.68 \%$

There are 15 trials for determining the risk of all grade hypertension including 13,070 patients (6911 in bevacizumab and 6159 in placebo group). The relative risk of hypertension with the patients treated with bevacizumab and concurrent therapy was 3.509 times more than placebo and concurrent therapy with 2.451 to 5.023 C.I and the $\mathrm{p}$ value statistically significant in random effect model.

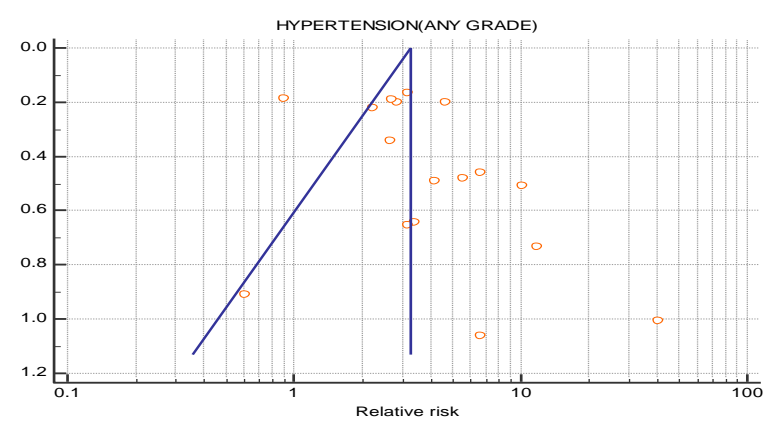

Figure 2: Funnel plot of bevacizumab vs placebo of all grade hypertension.

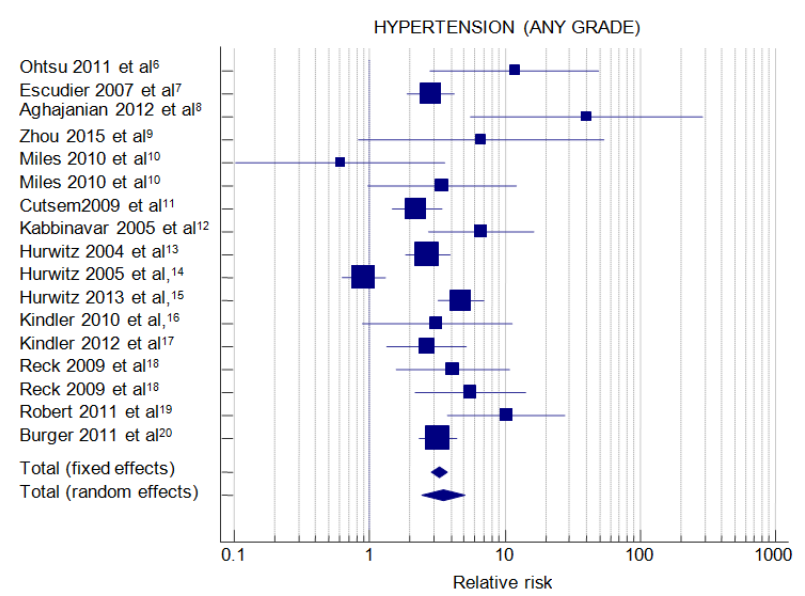

Figure 3: Forest plot of bevacizumab vs placebo of all grade hypertension.

There are 11 trials for determining the risk of grade 3 hypertension including 8799 patients $(4550$ in bevacizumab group and 4249 in placebo group). The 
relative risk of hypertension with the patients treated with bevacizumab and concurrent therapy was 3.909 times more than placebo and concurrent therapy with 1.983 to
7.707C.I and the $\mathrm{p}$ value statistically significant in random effect model.

Table 4: Relative risk of hypertension with bevacizumab of grade 3 and above.

\begin{tabular}{|c|c|c|c|c|c|c|c|c|}
\hline \multirow{2}{*}{ Study } & \multirow{2}{*}{$\begin{array}{l}\text { Bevacizumab } \\
\text { (N) }\end{array}$} & \multirow{2}{*}{$\begin{array}{l}\text { Placebo } \\
\text { (N) }\end{array}$} & \multirow{2}{*}{$\begin{array}{l}\text { Relative } \\
\text { risk }\end{array}$} & \multirow{2}{*}{$95 \% \mathrm{CI}$} & \multirow{2}{*}{$\mathbf{z}$} & \multirow{2}{*}{$\begin{array}{l}P \\
\text { value }\end{array}$} & \multicolumn{2}{|c|}{ Weight (\%) } \\
\hline & & & & & & & Fixed & Random \\
\hline Escudier et al $^{7}$ & $11 / 337$ & $2 / 304$ & 4.961 & 1.109 to 22.206 & & & 2.40 & 7.71 \\
\hline${\text { Aghajanian et } \text { al }^{8}}$ & $43 / 247$ & $1 / 233$ & 40.563 & 5.631 to 292.193 & & & 1.38 & 6.04 \\
\hline Zhou et al ${ }^{9}$ & $7 / 140$ & $1 / 134$ & 6.700 & 0.835 to 53.732 & & & 1.25 & 5.72 \\
\hline Cutsem et al $^{11}$ & $10 / 296$ & $3 / 287$ & 3.232 & 0.899 to 11.624 & & & 3.29 & 8.59 \\
\hline Kabbinavar et al ${ }^{12}$ & $16 / 100$ & $3 / 104$ & 5.547 & 1.667 to 18.456 & & & 3.73 & 8.91 \\
\hline Hurwitz et al $^{13}$ & $43 / 393$ & 9/397 & 4.826 & 2.385 to 9.766 & & & 10.86 & 10.91 \\
\hline Hurwitz et al ${ }^{14}$ & $20 / 109$ & $3 / 98$ & 5.994 & 1.837 to 19.554 & & & 3.86 & 8.99 \\
\hline Hurwitz et al ${ }^{15}$ & $153 / 1990$ & $29 / 1773$ & 4.701 & 3.177 to 6.955 & & & 35.16 & 11.88 \\
\hline Kindler et al ${ }^{16}$ & $10 / 277$ & $3 / 263$ & 3.165 & 0.881 to 11.373 & & & 3.30 & 8.59 \\
\hline Kindler et al $^{17}$ & $23 / 53$ & $9 / 55$ & 2.652 & 1.354 to 5.193 & & & 11.95 & 11.03 \\
\hline${\text { Burger et } \text { al }^{20}}^{20}$ & $24 / 608$ & $43 / 601$ & 0.552 & 0.339 to 0.897 & & & 22.80 & 11.63 \\
\hline Total (fixed effects) & $360 / 4550$ & $106 / 4249$ & 3.225 & 2.606 to 3.990 & 10.781 & $<0.001$ & 100.00 & 100.00 \\
\hline Total (random effects) & $360 / 4550$ & $106 / 4249$ & 3.909 & 1.983 to 7.707 & 3.937 & $<0.001$ & 100.00 & 100.00 \\
\hline
\end{tabular}

Heterogeneity $\mathrm{Q}=64.6768$, degree of freedom $=10, \mathrm{p}<0.0001, \mathrm{I}^{2}$ (inconsistency) $=85.54 \%$.

Table 5: Relative risk of hypertension at low dose $(2.5 \mathrm{mg} / \mathrm{kg} / \mathrm{cycle})$ in bevacizumab versus placebo.

\begin{tabular}{|c|c|c|c|c|c|c|c|c|}
\hline \multirow{2}{*}{ Study } & \multirow{2}{*}{$\begin{array}{l}\text { Bevacizumab } \\
\text { (N) }\end{array}$} & \multirow{2}{*}{$\begin{array}{l}\text { Placebo } \\
\text { (N) }\end{array}$} & \multirow{2}{*}{$\begin{array}{l}\text { Relative } \\
\text { risk }\end{array}$} & \multirow{2}{*}{$95 \%$ CI } & \multirow[b]{2}{*}{$\mathbf{z}$} & \multirow{2}{*}{$\begin{array}{l}P \\
\text { value }\end{array}$} & \multicolumn{2}{|c|}{ Weight (\%) } \\
\hline & & & & & & & Fixed & Random \\
\hline Ohtsu et al ${ }^{6}$ & $24 / 386$ & $2 / 381$ & 11.845 & 2.819 to 49.771 & & & 2.10 & 9.73 \\
\hline Miles et al ${ }^{10}$ & $2 / 252$ & $3 / 231$ & 0.611 & 0.103 to 3.625 & & & 1.36 & 7.65 \\
\hline Cutsem et al $^{11}$ & $60 / 296$ & $26 / 287$ & 2.238 & 1.455 to 3.442 & & & 23.33 & 18.08 \\
\hline Kabbinavar et al ${ }^{12}$ & $32 / 100$ & $5 / 104$ & 6.656 & 2.702 to 16.399 & & & 5.32 & 14.05 \\
\hline Hurwitz et al ${ }^{13}$ & $88 / 393$ & $33 / 397$ & 2.694 & 1.851 to 3.919 & & & 30.76 & 18.46 \\
\hline Hurwitz et al ${ }^{14}$ & $37 / 109$ & $37 / 98$ & 0.899 & 0.624 to 1.295 & & & 32.47 & 18.53 \\
\hline Reck et $_{\text {al }}{ }^{18}$ & $21 / 330$ & $5 / 327$ & 4.162 & 1.588 to 10.905 & & & 4.66 & 13.50 \\
\hline Total (fixed effects) & $264 / 1866$ & $111 / 1825$ & 2.312 & 1.887 to 2.833 & 8.082 & $<0.001$ & 100.00 & 100.00 \\
\hline Total (random effects) & $264 / 1866$ & $111 / 1825$ & 2.640 & 1.408 to 4.950 & 3.026 & 0.002 & 100.00 & 100.00 \\
\hline
\end{tabular}

Heterogeneity $\mathrm{Q}=40.2178$, degree of freedom $=6, \mathrm{p}<0.0001, \mathrm{I}^{2}$ (inconsistency) $=85.08 \%$.

Table 6: Relative risk of hypertension at high dose $(5 \mathrm{mg} / \mathrm{kg} / \mathrm{cycle})$ in bevacizumab versus placebo.

\begin{tabular}{|c|c|c|c|c|c|c|c|c|}
\hline \multirow{2}{*}{ Study } & \multirow{2}{*}{$\begin{array}{l}\text { Bevacizumab } \\
\text { (N) }\end{array}$} & \multirow{2}{*}{$\begin{array}{l}\text { Placebo } \\
(\mathbf{N})\end{array}$} & \multirow{2}{*}{$\begin{array}{l}\text { Relative } \\
\text { risk }\end{array}$} & \multirow{2}{*}{$95 \% \mathrm{CI}$} & \multirow{2}{*}{$\mathbf{z}$} & \multirow{2}{*}{$\begin{array}{l}P \\
\text { value }\end{array}$} & \multicolumn{2}{|c|}{ Weight (\%) } \\
\hline & & & & & & & Fixed & Random \\
\hline Escudier et al ${ }^{7}$ & $88 / 337$ & 28/304 & 2.835 & 1.908 to 4.213 & & & 22.33 & 18.76 \\
\hline Aghajanian et al ${ }^{8}$ & $43 / 247$ & $1 / 233$ & 40.563 & 5.631 to 292.193 & & & 0.90 & 2.31 \\
\hline Zhou et al ${ }^{9}$ & $7 / 140$ & $1 / 134$ & 6.700 & 0.835 to 53.732 & & & 0.81 & 2.10 \\
\hline Miles et $a^{10}$ & $11 / 247$ & $3 / 231$ & 3.429 & 0.969 to 12.137 & & & 2.19 & 5.02 \\
\hline Hurwitz et al ${ }^{15}$ & $153 / 1990$ & 29/1773 & 4.701 & 3.177 to 6.955 & & & 22.81 & 18.88 \\
\hline Kindler et al $^{16}$ & $10 / 277$ & $3 / 263$ & 3.165 & 0.881 to 11.373 & & & 2.14 & 4.92 \\
\hline Kindler et al $^{17}$ & $23 / 53$ & 9/55 & 2.652 & 1.354 to 5.193 & & & 7.75 & 12.03 \\
\hline Reck et al ${ }^{18}$ & $28 / 329$ & $5 / 327$ & 5.566 & 2.176 to 14.237 & & & 3.97 & 7.89 \\
\hline Robert et al ${ }^{19}$ & $81 / 817$ & $4 / 413$ & 10.237 & 3.777 to 27.740 & & & 3.52 & 7.24 \\
\hline Burger et $\mathrm{al}^{20}$ & $139 / 608$ & $43 / 601$ & 3.195 & 2.314 to 4.413 & & & 33.58 & 20.85 \\
\hline Total (fixed effects) & $583 / 5045$ & $126 / 4334$ & 4.134 & 3.426 to 4.988 & 14.817 & $<0.001$ & 100.00 & 100.00 \\
\hline Total (random effects) & $583 / 5045$ & $126 / 4334$ & 4.036 & 2.948 to 5.525 & 8.704 & $<0.001$ & 100.00 & 100.00 \\
\hline
\end{tabular}

Heterogeneity $\mathrm{Q}=17.1782$, degree of freedom $=9, \mathrm{p}=0.0462, \mathrm{I}^{2}$ (inconsistency) $=47.61 \%$. 
There are 7 trials for determining the risk of hypertension at low dose $(2.5 \mathrm{mg} / \mathrm{kg} / \mathrm{cycle})$ including 3691 patients (1866 in bevacizumab group and 1825 in placebo group). The relative risk of hypertension with the patients treated with bevacizumab and concurrent therapy was 2.640 times more than placebo and concurrent therapy with 1.408 to 4.950 C.I and the $\mathrm{p}$ value statistically significant in random effect model.

There are 10 trials for determining the risk of hypertension at high dose $(5 \mathrm{mg} / \mathrm{kg} /$ cycle $)$ including 9379 patients (5045 in bevacizumab group and 4334 in placebo group). The relative risk of hypertension with the patients treated with bevacizumab and concurrent therapy was 4.036 times more than placebo and concurrent therapy with 2.948 to 5.525 C.I and the $p$ value statistically significant in random effect model.

\section{DISCUSSION}

Our meta-analysis shows that bevacizumab is associated with a significant increased risk of hypertension in patients who received treatment for metastatic cancers of lung,ovarian, colorectum, pancreatic and kidney which were similar to the results of study of Xiaolei Zhu, Shenhong Wu, William L. Dahut, Chirag R. Parikh. With the increasing use of angiogenesis inhibitors in patients with several metastatic cancers because of the associated survival benefit, it is important that oncologists, internists, and nephrologists monitor and manage these side effects appropriately to ensure that patients receive maximum benefit from bevacizumab therapy.

As expected, hypertension of grade 3 or higher was significantly more common with bevacizumab than without it. Although the risk of hypertension appeared to be cumulative. ${ }^{21,22}$ The clinical significance of severe hypertension is evident because of associated cardiovascular complications. Indeed, severe hypertension can require hospitalization or discontinuation of bevacizumab in many of patients; complications may include hypertensive encephalopathy, central nervous system hemorrhage, reversible posterior leukoencephalopathy, and congestive heart failure. ${ }^{23}$ In addition, high-grade hypertension may lead to arterial thromboembolic events, which were significantly increased in cancer patients treated with bevacizumab. $^{24}$ Therefore, it is particularly important for all health-care providers and patients to recognize the risk, and to monitor and treat hypertension timely and appropriately.

Efforts are ongoing to understand the mechanism of hypertension associated with angiogenesis inhibitors. The binding of VEGF to its corresponding receptors can enhance microvascular permeability, initiate cell division and migration, and impede apoptosis and senescence. Inhibition of VEGF effect may cause decreased endothelial renewal capacity and increased apoptosis. In addition, it interferes with endothelial cell production of vasodilators such as nitrous oxide and prostacyclin, leading to vasoconstriction. Similar effects of VEGF antagonism in kidneys may contribute to the development of hypertension. Appropriate VEGF expression in endothelial cells and podocytes of kidneys maintains a normal glomerular structure and function. Disruption of the VEGF signaling pathway leads to inhibition of nitric oxide synthase, thereby reducing nitric oxide and prostacyclin synthesis. This in turn renders a vasoconstrictive effect and decreased sodium ion renal excretion, resulting in elevated blood pressure. In addition, hypertension may be related to vascular rarefaction, a functional decrease in the number of arterioles and capillaries generating an increase in peripheral vascular resistance. ${ }^{25}$

In clinical trials, bevacizumab-associated hypertension was managed with oral antihypertensive medications. The choice of antihypertensive therapy for management of this secondary hypertension is still under debate.

\section{CONCLUSION}

The association of hypertension with new agents presents a challenge for recognition because many RCTs may not be powered to reveal a significant relationship. Our metaanalysis of 15 RCTs has overcome this limitation of individual trials and demonstrated that bevacizumab may be associated with a significantly increased risk of hypertension in patients with a variety of metastatic solid tumors irrespective of dosing.

\section{Funding: No funding sources Conflict of interest: None declared Ethical approval: Not required}

\section{REFERENCES}

1. Ferrara N. Vascular endothelial growth factor: basic science and clinical progress. Endocrine Rev. 2004;4(25):581-611.

2. Kerbel RS. Tumor angiogenesis. N Eng J Med. 2008;19(358):2039-49.

3. Xiaolei Z, Wu S, Dahut WL, Parikh CR. Risks of proteinuria and hypertension with bevacizumab, an antibody against vascular endothelial growth factor: systematic review and meta-analysis. Am J Kidney Dis. 2007;2(49):186-93.

4. Karrison T, Kindler HL, Gandara DR, Lu C, Guterz TL, Nichols K, et al. Final analysis of a multi-center, double-blind, placebo-controlled, randomized phase II trial of gemcitabine/cisplatin (GC) plus bevacizumab (B) or placebo $(\mathrm{P})$ in patients (pts) with malignant mesothelioma (MM). ASCO Meeting Abstracts. 2007;25:7526.

5. Beller EM, Glasziou PP, Altman DG. PRISMA for Abstracts: Reporting Systematic Reviews in Journal and Conference Abstracts. PLoS Med. 2013;10(4):e1001419. 
6. Ohtsu A, Shah MA, Van Cutsem E, Rha SY, Sawaki A, Park SR, et al. Bevacizumab in combination with chemotherapy as first-line therapy in advanced gastric cancer: a randomized, double-blind, placebocontrolled phase III study. J Clin Oncol. 2011;29(30):3968-76.

7. Escudier B, Pluzanska A, Koralewski P, Ravaud A, Bracarda S, Szczylik C, et al. Bevacizumab plus interferon alfa-2a for treatment of metastatic renal cell carcinoma: a randomised, double-blind phase III trial. The Lancet. 2007;370(9605):2103-11.

8. Aghajanian C, Blank SV, Goff BA, Judson PL, Teneriello MG, Husain A, et al. A randomized, double-blind, placebo-controlled phase III trial of chemotherapy with or without bevacizumab in patients with platinum-sensitive recurrent epithelial ovarian, primary peritoneal, or fallopian tube cancer. J Clin Oncol. 2012;30(17):2039.

9. Zhou C, Wu YL, Chen G, Liu X, Zhu Y, Lu S, et al. BEYOND. A randomized, double-blind, placebocontrolled, multicenter, phase III study of first-line carboplatin/paclitaxel plus bevacizumab or placebo in Chinese patients with advanced or recurrent nonsquamous non-small-cell lung cancer. J Clin Oncol. 2015;33(19):2197-204.

10. Miles DW, Chan A, Dirix LY, Cortés J, Pivot X, Tomczak P, et al. Phase III study of bevacizumab plus docetaxel compared with placebo plus docetaxel for the first-line treatment of human epidermal growth factor receptor 2-negative metastatic breast cancer. J Clin Oncol. 2010;28(20):3239-47.

11. Van Cutsem E, Vervenne WL, Bennouna J, Humblet Y, Gill S, Van Laethem JL, et al. Phase III trial of bevacizumab in combination with gemcitabine and erlotinib in patients with metastatic pancreatic cancer. J Clin Oncol. 2009;27(13):2231-7.

12. Kabbinavar FF, Schulz J, McCleod M, Patel T, Hamm JT, Hecht JR, et al. Addition of bevacizumab to bolus fluorouracil and leucovorin in first-line metastatic colorectal cancer: results of a randomized phase II trial. J Clin Oncol. 2005;23(16):3697-705.

13. Hurwitz H, Fehrenbacher L, Novotny W, Cartwright T, Hainsworth J, Heim W, et al. Bevacizumab plus irinotecan, fluorouracil, and leucovorin for metastatic colorectal cancer. N Eng J Med. 2004;350(23):233542.

14. Hurwitz HI, Fehrenbacher L, Hainsworth JD, Heim $\mathrm{W}$, Berlin J, Holmgren E, et al. Bevacizumab in combination with fluorouracil and leucovorin: an active regimen for first-line metastatic colorectal cancer. J Clin Oncol. 2005;23(15):3502-8.

15. Hurwitz HI, Tebbutt NC, Kabbinavar F, Giantonio BJ, Guan ZZ, Mitchell L, et al. Efficacy and safety of bevacizumab in metastatic colorectal cancer: pooled analysis from seven randomized controlled trials. The Oncol. 2013;18(9):1004-12.
16. Kindler HL, Niedzwiecki D, Hollis D, Sutherland S, Schrag D, Hurwitz H, et al. Gemcitabine plus bevacizumab compared with gemcitabine plus placebo in patients with advanced pancreatic cancer: phase III trial of the Cancer and Leukemia Group B (CALGB 80303). J Clin Oncol. 2010;28(22):3617.

17. Kindler HL, Karrison TG, Gandara DR, Lu C, Krug LM, Stevenson JP, et al. Multicenter, double-blind, placebo-controlled, randomized phase II trial of gemcitabine/cisplatin plus bevacizumab or placebo in patients with malignant mesothelioma. J Clin Oncol. 2012;30(20):2509.

18. Reck M, von Pawel J, Zatloukal P, Ramlau R, Gorbounova V, Hirsh V, et al. Phase III trial of cisplatin plus gemcitabine with either placebo or bevacizumab as first-line therapy for nonsquamous non-small-cell lung cancer: AVAiL. J Clin Oncol. 2009;27(8):1227-34.

19. Robert NJ, Diéras V, Glaspy J, Brufsky AM, Bondarenko I, Lipatov ON, et al. RIBBON-1: randomized, double-blind, placebo-controlled, phase III trial of chemotherapy with or without bevacizumab for first-line treatment of human epidermal growth factor receptor 2-negative, locally recurrent or metastatic breast cancer. J Clin Oncol. 2011;29(10):1252-60.

20. Burger RA, Brady MF, Bookman MA, Fleming GF, Monk BJ, Huang $\mathrm{H}$, et al. Incorporation of bevacizumab in the primary treatment of ovarian cancer. N Eng J Med. 2011;365(26):2473-83.

21. Gordon MS, Cunningham D. Managing patients treated with bevacizumab combination therapy. Oncology. 2005;69(Suppl. 3):25-33.

22. Pande AU, Lombardo JC, Fakih M, Wong MK, Iyer RV, Kuvshinoff BW, Javle MM. Bevacizumab (BV) induced hypertension (HT): A manageable toxicity. J Clin Oncol. 2006;24(18_suppl):13539.

23. Ranpura V, Hapani S, Wu S. Treatment-related mortality with bevacizumab in cancer patients: a meta-analysis. JAMA. 2011;305(5):487-94.

24. Scappaticci FA, Skillings JR, Holden SN, Gerber HP, Miller K, Kabbinavar F, et al. Arterial thromboembolic events in patients with metastatic carcinoma treated with chemotherapy and bevacizumab. J National Cancer Institute. 2007;99(16):1232-9.

25. Ranpura V, Pulipati B, Chu D, Zhu X, Wu S. Increased risk of high-grade hypertension with bevacizumab in cancer patients: a meta-analysis. Am J Hypertension. 2010;23(5):460-8.

Cite this article as: Shah MK, Shah MA, Shah SD. Risk of hypertension with bevacizumab, an antibody against vascular endothelial growth factor A: a systematic review and meta-analysis. Int J Basic Clin Pharmacol 2019;8:2354-60. 